AGENT-BASED COMPUTER SIMULATION OF

DICHOTOMOUS ECONOMIC GROWTH 


\section{Advances in Computational Economics}

\section{VOLUME 13}

\section{SERIES EDITORS}

Hans Amman, University of Amsterdam, Amsterdam, The Netherlands Anna Nagurney, University of Massachusetts at Amherst, USA

\section{EDITORIAL BOARD}

Anantha K. Duraiappah, European University Institute

John Geweke, University of Minnesota

Manfred Gilli, University of Geneva

Kenneth L. Judd, Stanford University

David Kendrick, University of Texas at Austin

Daniel McFadden, University of California at Berkeley

Ellen McGrattan, Duke University

Reinhard Neck, University of Klagenfurt

Adrian R. Pagan, Australian National University

John Rust, University of Wisconsin

Berc Rustem, University of London

Hal R. Varian, University of Michigan

The titles published in this series are listed at the end of this volume. 


\title{
Agent-Based Computer Simulation of Dichotomous Economic Growth
}

\author{
by \\ Roger A. McCain
}

Drexel University, Philadelphia, PA, USA

Springer Science+Business Media, LLC 


\section{Library of Congress Cataloging-in-Publication Data}

McCain, Roger A.

Agent-based computer simulation of dichotomous economic growth/by Roger A. McCain. p.cm.--(Advances in computational economics; v.13)

Includes bibliographical references and index.

ISBN 978-1-4613-7085-7 ISBN 978-1-4615-4613-9 (eBook)

DOI 10.1007/978-1-4615-4613-9

1. Economic development--Mathematical models. 2. Econometric models--Computer simulation. I. Title. II. Series.

HD75.5.M39 1999

Copyright (C) 2000 Springer Science+Business Media New York

Originally published by Kluwer Academic Publishers, New York in 2000

Softcover reprint of the hardcover 1 st edition 2000

All rights reserved. No part of this publication may be reproduced, stored in a retrieval system or transmitted in any form or by any means, mechanical, photo-copying, recording, or otherwise, without the prior written permission of the publisher, Springer Science+Business Media, LLC.

Printed on acid-free paper. 
This book is dedicated to the memory of Mary Gharst McCain, who wanted me to be a lawyer. 


\section{CONTENTS}

ACKNOWLEDGMENT ix

1 INTRODUCTION 1

2 DICHOTOMIZATION WITHOUT STEADY GROWTH:

BASELINE SIMULATIONS 5

Figures for Chapter 2

3 STEADY ECONOMIC GROWTH: THE COBB-DOUGLAS

CASE WITH "ENGINEERING- SCHOOL" HUMAN CAPITAL 31

Figures for Chapter 3

4 SIMULATIONS OF STEADY ECONOMIC GROWTH WITH

A COBB-DOUGLAS PRODUCTION FUNCTION 39

Figures for Chapter 4

5 GROWTH WITH NON-UNITARY ELASTICITIES OF SUBSTITUTION

Figures for Chapter 5

6 LEARNING-BY-DOING AND THE PUZZLES OF

ECONOMIC GROWTH: SURVEY AND INTERPRETATION

Figure for Chapter 6

7 LEARNING BY DOING AND DICHOTOMOUS DEVELOPMENT 93

$\begin{array}{lr}\text { Figures for Chapter } 7 & 102\end{array}$

8 SIMULATIONS WITH IRREGULAR NEIGHBORHOODS 111

$\begin{array}{ll}\text { Figures for Chapter } 8 & 117\end{array}$

9 BOOLEAN TRADE NETWORKS 123

Figures for Chapter 9

10 BACKWASH AND SPREAD: TRADE NETWORKS IN

A SPACE OF AGENTS WHO LEARN BY DOING 131

$\begin{array}{ll}\text { Figures for Chapter } 10 & 136\end{array}$

11 CONCLUDING SUMMARY 141

REFERENCES $\quad 145$

$\begin{array}{ll}\text { APPENDIX: PROGRAM CODE } & 149\end{array}$

$\begin{array}{ll}\text { INDEX } & 161\end{array}$ 


\section{ACKNOWLEDGMENT}

This book has benefited from the examples, discussion and feedback provided by scholars attending the annual Conferences on Computation in Economics and Finance, sponsored by the Society for Computational Economics, Geneva, 1996, Palo Alto, 1997, and Cambridge, 1998. Particular thanks are due to the participants in the interest group on Agent-Based Computational Economics. The assistance, encouragement, suggestions, and collaboration of my wife, Katherine W. McCain, have also been invaluable. 